\title{
A Qualitative Course-Based Inquiry into the Concept of Love as a Central Component of Child and Youth Care Practice
}

\author{
Kylie Schneider \\ BCYC, MacEwan University, Alberta, Canada \\ Melanie Dziwenka \\ BCYC, MacEwan University, Alberta, Canada \\ Bobbi Schweighardt \\ BCYC, MacEwan University, Alberta, Canada \\ Gerard Bellefeuille* \\ Department of Child and Youth Care MacEwan University, Alberta, Canada
}

\begin{abstract}
Child and Youth Care (CYC) students have the right to be engaged in pedagogical practices that inspire and arouse their curiosity about their field of practice. Undergraduate course-based research in which students have an opportunity to conduct authentic research within a for-credit course is one such high-impact pedagogical practice with a growing body of evidence-based outcomes. This article presents an undergraduate course-based research project that examined child and youth care student's beliefs about displaying love as a component of their practice. Located in the constructivist/interpretive research paradigm, this course-based research project collected data through the use of an expressive arts-based data method followed by a semi-structured questionnaire. Four overarching themes were identified during the thematic analysis: (a) authentic caring involves expressions of love, (b) expressions of love are an essential component of growth and development, (c) loving care as an ethic of relational practice, and (d) but...professionalism stands in the way. The results of this course-based study suggest that expressing love as a component of relational-centred CYC practice is not fully understood by CYC students and that much more research is needed to explore this issue.
\end{abstract}

Keywords: Child and youth care; Love; Qualitative; Relational-centred practice.

\section{(a) (1) CC BY: Creative Commons Attribution License 4.0}

\section{Introduction}

Historically, the therapeutic relationship has been the core of child and youth care (CYC) practice, and practitioners involved in the field have long strived to embody the basic human virtues exemplified by relationalcentred practice. Bellefeuille et al. (2017), for example, consider relational-centred CYC practice to be a deeply intrapersonal process that demands a genuine willingness on the part of the practitioner to engage in authentic caring. Relational-centred practice directs CYC practitioners to challenge the notion of arms-length boundaries defined by traditional professional practice and to enter the relational space with others in an authentic manner that involves getting personal (Bellefeuille et al., 2017). For example, language found in the literature and used in the classroom to describe relational-centred practice include terms such as trusting, honesty, empathy, caring, kindness, respect, and supportive. Interestingly, however, one word that is seldom mentioned is love. Why is that? The need to be loved, as (Bowlby, 1982) and other developmental theorists (Allen and Manning, 2007; Bretherton and Mulholland, 2008; Perry, 2019; Quartz and Sejnowski, 2002) have shown, is one of the most fundamental human needs and is a prerequisite of healthy development. Given that the need to be loved is hardwired in our brains and is such a powerful determinant of happiness, why are we not encouraged to consider expressions of love to be a basic component of relational-centred CYC practice? Scholars throughout the helping professions, including education, nursing, social work, and CYC, have written about the concept of love, yet there remains a great deal of uncertainty and uneasiness about love's place in professional relationships (Arman and Rehnsfeldt, 2006; Artz, 2000; Hooks, 2000; Smith, 2006;2011; Starratt, 1991; Stickley and Freshwater, 2002; Thich, 2007; Underwood, 2009). American psychiatrist and senior fellow of the Child Trauma Academy Dr. Bruce Perry states:

The most important property of humankind is the capacity to form and maintain relationships. These relationships are absolutely necessary for any of us to survive, learn, work, love and procreate. Human relationships take many forms, but the most intense, most pleasurable and most painful are those relationships with family, friends and loved ones. Within this inner circle of intimate relationships, we are bonded to each other with "emotional glue"-bonded with love. $(2019$, p.1) 


\subsection{The Concept of Love}

As a concept, love is at once clear and complex, is subjectively and objectively understood, and is embedded in many different assumptions (Stickley and Freshwater, 2002). For some, "love" is a catachresis-a word that has no literal referent and seems to come apart as it is articulated; for others, love originates from one's heart and is a natural human capacity to share and understand the sorrow, pain, and joy of others (Glöckler, 2002).

Dating back to late 1800 s, German physician and pioneering sexologist Richard von Krafft-Ebing (1886-1945) identified five types of love: true love, sentimental love, platonic love, friendship, and sensual love (Regan, 2008). In the mid '50s psychotherapist Albert Ellis proposed additional varieties of love and noted

"love itself ... includes many different types and degrees of affection, such as conjugal love,

parental love, familial love, religious love, love of humanity, love of animals, love of things, self-

love, sexual love, obsessive-compulsive love, etc." (1954, p. 101).

Following in Ellis's footsteps, religious theoretician C. S. Lewis proposed four main varieties of love, which he identified as (a) affectionate love, which has a "comfortable, quiet nature" (p. 34) and consists of feelings of warmth, interpersonal comfort, and satisfaction in being together; (b) friendship love characterized by common interests, mutual respect, and understanding; (c) eroslove ("the state of being in love") (p. 91), and (d) erotic love also characterized by "affection, idealization of and preoccupation with the beloved" (Regan, 2008).

For theologian, philosopher, and scholar Thomas (Oord, 2010), love is a force of nature that inspires intentional acts of sympathy toward others and promotes wellbeing. While Oord does not provide a definitive definition of love; instead, he does writes about what it means to practice love. He states, "To love is to act intentionally, in sympathetic response to others (including God), to promote overall well-being" (p. 15). For all the different grammatical ways in which love is used in everyday language, such as in its nominal form (i.e., love), in its verbal form (to love), and in its adjectival forms (loving and lovable), it is the adjectival form, 'loving', that is central to Oord's contemplation of the topic.

\subsection{A Question of Professional Boundaries}

The uneasiness that exists in relation to the subject or expression of love in CYC practice is primarily the result of concerns about transgressing professional boundaries. Historically, the professional boundaries created within the CYC field have been influenced by the traditional medical paradigm, which is rooted in the positivist Cartesian worldview. This framework maintains that professionals must be able to separate their personal experiences and emotions from their interactions with clients in the professional environment. As informed by this principle, many professional boundaries in the field of CYC are incongruent with the profession's unique relational-centred theoretical lens and value base. When considered from a relational-centred perspective CYC practitioners cannot devalue emotions to a set of defined behaviors or technical competencies. The topic examined in this study is not that of professional boundaries; instead, we seek to outline what form or forms love can take and how it can be manifested in CYC practice.

\section{Undergraduate Course-Based Research: A Pedagogical Tool to Foster Criticality, Reflectivity, and Praxis}

The Bachelor of Child and Youth Care program at MacEwan University is continuously searching for new pedagogical approaches to foster criticality, reflectivity, and praxis as integral components of the overall student educational experience. As such, the design and implementation of a course-based approach, in contrast with the traditional didactic approach to research-methods instruction, offers fourth-year undergraduate students the opportunity to master introductory research skills by conceptualizing, designing, administering, and showcasing small minimum-risk research projects under the guidance and supervision of the course instructor-commonly, a professor with an extensive background in research and teaching.

Use of course-based research in higher education has soared in recent years (Allyn, 2013; Bellefeuille et al., 2014; Harrison et al., 2010). The benefits derived from a course-based approach to teaching research methods for child and youth care students are significant. First, there is value in providing students with authentic learning experiences that enhance the transfer of knowledge obtained in formal education to practice. Previous students have reported that their engagement in course-based research has enabled them to expand their depth of scientific knowledge by adopting new methods of creative inquiry. Second, course-based research offers students the opportunity to work with instructors in a relationship characterized by mentoring, which results in a greater number of students who express interest in advancing to graduate studies. Third, the results of course-based research can sometimes be published in peer-reviewed journals and online open-access portals, and thus contribute to the discipline's knowledge base.

Ethical approval required to enable students to conduct course-based research projects is granted to the course instructor by the university's research ethics board (REB). Student research groups are then required to complete a REB application form for each course-based research project undertaken in the class, which is then reviewed by the course instructor and a sub-REB committee to ensure each project is completed and is in compliance with the ethics review requirements of the university.

\section{Research Paradigm}

This course-based research project was situated within the paradigm of interpretive research because the information sought reflected the beliefs, boundaries, and personal ethics of participants. Interpretivist enquiry is 
intimately associated with qualitative studies and is used to unearth in-depth information about a phenomenon, particularity when very little is known about a topic or when new perspectives are needed Creswell (2013). Interpretivism is unlike the positivist research paradigm that takes as its goal the discovery of a single correct response. Interpretivism is much more inclusive, because it integrates and considers multiple viewpoints of different individuals from different groups (Creswell, 2013). As Klen and Meyers (1998) suggest, the acceptance of multiple perspectives in interpretivism often leads to a more inclusive understanding of the phenomenon that is the topic of inquiry.

\section{Research Design}

The interpretivist-constructivist paradigm is predominantly used in qualitative inquiries (Nind and Todd, 2011; Willis, 2007) for which information is gathered directly from those who experience the phenomenon under investigation. As Creswell (2013) and Schwandt (2000) explain, qualitative research designs offer rich data that is necessary for interpretivists to fully understand contexts. Given the interpretive emphasis this course-based study, a qualitative research design was used to capture the perceptions of study participants regarding the application of love in CYC practice. The course-based research project is exploratory in nature because it is asking participants how they express love in their practice.

\subsection{Sampling Strategy}

A non-probability, convenience sample was used to recruit first-, second-, third-, and fourth-year CYC students as participants in this course-based research study. Non-probability sampling is widely used in qualitative research to identify and select information-rich cases relevant to subject of inquiry (Patton, 2002). A total of twenty-five students participated in the course-based research study, which included first-year students, second-year students, third-year students, and fourth-year students. All participants were given an information letter and a consent form to sign prior to participation.

\subsection{Statement of Research Question}

The specific course-based research question was the following: How do child and youth care students apply love in their practice?

\subsection{Data Collection}

Two data collection strategies were used to collect data for this course-based study. First, an expressive arts-based method was used to encourage each participant to create an expressive image to demonstrate how he or she applies "love" in their practice. Participants were given a choice to draw an image, create a word map, or take a photo. Creative and arts-based research methods are increasingly used to highlight the ontological, epistemological, theoretical, methodological, and representative elements of qualitative research (Angelides and Michaelidou, 2009; Bagnoli, 2009; Leavy, 2009; The Coemans and Hannes, 2017; Woodgate et al., 2017). University professor Shaun McNiff and author of McNiff (2007) defines art-based research

as the systematic use of the artistic process, the actual making of artistic expressions in all of the different forms of the arts, as a primary way of understanding and examining experience by both researchers and the people that they involve in their studies. (p. 29)

Second, an open-ended semi-structured questionnaire was used to capture the perceptions of the CYC student participants about the expression of love as a component of their practice.

\subsection{Data Analysis}

Data was analyzed using Braun and Clarke (2006) six stages of thematic analysis techniques: (1) familiarizing oneself with the data, (2) generating initial codes, (3) searching for themes, (4) reviewing and refining themes, (5) defining and naming themes, and (6) producing a report. First, data were reviewed over and over, and ideas were identified in a process of familiarization. Initial codes were identified and clustered into thematic categories. A code is defined as something that captures the key idea about the data in relation to the research question and represents some level of patterned response or meaning within the data set (Braun and Clarke). The thematic analysis resulted in the identification of themes. These include: (a) authentic caring involves expressions of love, (b) expressions of love are an essential component of growth and development, (c) loving care as an ethic of relational practice (d) but...Professionalism stands in the way. Each is discussed below.

\subsection{Authentic Caring Involves Expressions of Love}

The skill of being authentic with others is at the core of relational-centred CYC practice. Child and youth care students are regularly encouraged to resist the traditional practice of maintaining an arm's length separation between the professional and client because this constrains the ability to express a genuine and authentic caring that is essential to an effective therapeutic process. Not surprisingly, the majority of participants described their expression of loving behaviour as a display of their authenticity. One participant claimed, "It doesn't seem possible to not include love". Another participant said, "I use love because it's the only thing I know how to do. I think love is was makes me an effective child and youth care practitioner". Authenticity, as characterized and taught in CYC education, involves a sincere effort to go inside oneself. As one participant noted, "I need to [apply love] in order to be true to who I am and how I keep the kids seeing that I care". In summary, participants underscored the fundamental importance of authenticity as a component of the helping relationship. Moreover, CYC practitioners must encounter and recognize 
their clients as human beings and be willing to reveal their genuine selves rather than present as professionals fulfilling a role.

\subsection{Expressions of love are Essential Components of Growth and Development}

An understanding of child development theory is an essential component of CYC education. According to all of the major developmental theories, one important element all children and youth must have in order to develop into healthy, well-adjusted adults is feeling loved by at least one significant person in their life. Many participants described meeting a child's basic needs as an important expression of love; at the same time, they cited various developmental theories. For example, one participant said, "Love-or feeling loved —is how we know we belong, which you may recall is one of the pillars of the hierarchy of needs". Another participant referenced attachment theory, stating that "Love and attachment need each other." Participants also contributed these observations: "I have told clients I love them and gave them hugs and loving gestures, too, when they seem to need the affirmation, and even just to strengthen existing healthy bonds"; "meaningful connection is crucial to change"; and "love is a fundamental human need."

\subsection{Loving Care as an Ethic of Relational Practice}

Many participants interpreted and described the act of caring as a virtue and an act of ethics inseparably related to love as a core CYC value. They talked about how the love they had for a child or youth that exceeded professional boundaries and noted the moral challenge of being emotionally available to their clients. Comments included, "I would want someone to love me", "I don't want to be another individual who denies them the feeling of someone caring [for them] on that level", and "How could we work with those who are struggling if we lack compassion or empathy, patience, or respect". In a relational-centred profession like CYC, where daily interactions include engaging in helping and supporting others in the context of a professional caring relationship, the participants in this course-based inquiry identified love as an essential ethical element of their practice.

\subsection{But...Professionalism Stands in the Way}

Last, participants also expressed hesitation and uncertainty about over-stepping the "arm's-length" boundaries that have traditionally defined professional-client relationships. This concern was reflected in this participant's statement: "I think fear of professional boundaries; work policy and ethics creates a divide in some cases". The inner voice of many participants cautioned them to avoid crossing professional boundaries. While participants felt a desire to get closer to their clients; their fear of crossing professional boundaries prevented them from doing so.

\section{Discussion}

The findings present two different perceptions held by CYC students about the nature of their relational work with children, youth, and families. The first, and more prominent impulse, focused on the importance of expressing love as a necessary aspect of relational practice. The second element was the fear of crossing professional boundaries in their CYC worker-client relationships. Participants recognized that the close nature and quality of these relationships are central to relational-centred CYC practice. Further discussion about the intersection of professionalism and relational practice is needed to help ensure students have opportunities to reflect on and demonstrate their thinking in the classroom.

\section{References}

Allen, J. P. and Manning, N. (2007). From safety to affect regulation: Attachment from the vantage point of adolescence. New Directions in Child and Adolescent Development, 117: 23-39. Available: https://www.ncbi.nlm.nih.gov/pubmed/17876787

Allyn, D. A. (2013). Course-based undergraduate research-It can be accomplished! Journal of Physical Education, Recreation \& Dance, 84(9): 32-36.

Angelides, P. and Michaelidou, A. (2009). The deafening silence: Discussing children's drawings for understanding and addressing marginalization. Journal of Early Childhood Research, 7(1): 27-45.

Arman, M. and Rehnsfeldt, A. (2006). The presence of love in ethical caring. Nursing Forum, 41(1): 4-12.

Artz, S. (2000). The meaning of Love in the teaching and healing arts. Child \& Youth Care Forum, 29(5): $293-98$.

Bagnoli, A. (2009). Beyond the standard interview: The use of graphic elicitation and arts-based methods. Qualitative Research, 9(5): 547-70.

Bellefeuille, G., Ricks, F. and Jamieson, D. (2017). Standing on the precipice: Inquiry into the creative potential of child and youth care practice. 2nd ed edn: AB: MacEwan Press: Edmonton.

Bellefeuille, G., Ekdahl, C., Kent, L. and Kluczny, M. (2014). A course-based creative inquiry approach to teaching introductory research methods in Child and Youth Care undergraduate education. International Journal of Teaching and Education, 2(2): 1-9.

Bowlby, J. (1982). Attachment: Attachment and loss. Basic Books: New York, NY. 1:

Braun, V. and Clarke, V. (2006). Using thematic analysis in psychology. Qualitative Research in Psychology 3(2): 77101.

Bretherton, I. and Mulholland, K. A. (2008). Internal working models in attachment relationships: Elaborating a central construct in attachment theory. In J. Cassidy \& P. R. Shaver (Eds.), Handbook of attachment: Theory, research, and clinical applications. NY: Guilford Press: New York. 102-27. 
Creswell, J. W. (2013). Qualitative inquiry and research design: Choosing among five approaches. 3rd ed. edn: CA: Sage: Thousand Oaks.

Glöckler, M. (2002). Kärleken som förvandlingskraft. Bokförlaget Fenix: Stockholm Sweden.

Harrison, M., Dunbar, D., Ratmansky, L., Boyd, K. and Lopatto, D. (2010). Classroom-based science research at the introductory level: Changes in career choices and attitude. CBE Life Sciences Education, 10(3): 279-86.

Hooks, B. (2000). All about love: New visions. Harper Perennial: New York, NY.

Klen, H. and Meyers, M. (1998). A set of principles for conducting and evaluating interpretive field studies in information systems. Available: http://www.auckland.au.nz/msis/isworld/MMyers/Klein-Myers.html

Leavy, P. (2009). Method meets art: Arts-based research practice. NY: Guilford Press: New York.

McNiff, S. (2007). Arts-based research. In J. G. Knowles \& A. L. Cole (Eds.), Handbook of the arts in qualitative research. Thousand Oaks, CA: AltaMira Press. 29-40.

Nind, M. and Todd, L. (2011). Prospects for educational research. International Journal Of Research \& Method In Education, 1(34): 1-2.

Oord, T. (2010). Defining love: A philosophical, scientific, and theological engagement. Grande Rapids, MI: Brazos Press.

Patton, M. Q. (2002). Qualitative research and evaluation methods. 3rd ed. edn: CA: Sage: : Thousand Oaks.

Perry, B. D. (2019). Bonding and attachment in maltreated children: Consequences of emotional neglect in childhood. Available: https://childtrauma.org/wp-content/uploads/2013/11/Bonding 13.pdf

Quartz, S. R. and Sejnowski, T. J. (2002). The neural basis of cognitive development: About how we become who we are. NY: Harper-Collins: New York.

Regan, P. (2008). The mating game: A primer on love, sex, and marriage. CA: Sage: Thousand Oaks.

Schwandt, T. A. (2000). Three epistemological stances for qualitative inquiry: Interpretivism, hermeneutics, and social constructionism. In n.K. Denzin and y.S. Lincoln (eds.), handbook of qualitative research. 2 nd ed. CA.: Sage: Thousand Oaks. 189-214.

Smith, M. (2006). Act justly, love tenderly, walk humbly. Relational Child and Youth Care Practice, 19(4): 5-17.

Smith, M. (2011). Love and the child and youth care relationship. Relational Child and Youth Care Practice, 24(1-2): 189-92.

Starratt, R. (1991). Building an ethical school: A theory for practice in educational leadership. Educational Administration Quarterly, 27(2): 185-202.

Stickley, T. and Freshwater, D. (2002). The art of loving and the therapeutic relationship. Nursing Inquiry, 9(4): 25056.

The Coemans, S. and Hannes, K. (2017). Researchers under the spell of the arts: Two decades of using arts-based methods in community-based inquiry with vulnerable populations. Educational Research Review, 22: 34-49. Available: https://www.sciencedirect.com/science/article/pii/S1747938X17300301

Thich, N. H. (2007). Teachings on love. CA: Parallax Press: Berkeley.

Underwood, L. G. (2009). Compassionate love: A framework for research. In B. Fehr, S. Sprecher, \& L. G. Underwood (Eds.), The science of compassionate love: Theory, research, and applications. Wiley-Blackwell: Chichester. 3-25.

Willis, J. W. (2007). Foundations of qualitative research: Interpretive and critical approaches. Sage: London, England.

Woodgate, R. L., Zurba, M. and Tennent, P. (2017). Worth a thousand words? Advantages, challenges and opportunities in working with photovoice as a qualitative research method with youth and their families. Forum Qualitative Sozialforschung / Forum: Qualitative Social Research, 18(1): 2. 